\title{
CLIMATE CHANGE AND HUMAN DEVELOPMENT: EXTENDING THE VISION OF DR. MAHBUB UL HAQ
}

\author{
Sumanasiri Liyanage ${ }^{*}$ \\ Anuruddha Kankanamge** \\ Does Critical Criticism believe that it has \\ reached even the beginning of a knowledge of \\ historical reality so long as it excludes from \\ the historical movement the theoretical and \\ practical relation of man to nature, i.e. \\ natural science and industry? \\ -KARL MARX AND FREDERICK ENGELS \\ For it is because we are kept in the \\ dark about the nature of human \\ society-as opposed to nature in \\ general - that we are now faced (so \\ the scientists concerned assure me), \\ by the complete destructibility of this \\ planet that has barely been made fit \\ to live in.
}

-BERTOLT BRECHT

\begin{abstract}
Climate change is not a "natural" disaster, but a creation of the system that is aimed in pursuit of private profit at increasing scale. The implications and effects of climate change can be considered as one of the key factors in determining not only the welfare of human being but also the existence of other life forms and our planet. The principal submission of this paper is, extending and advancing the insight of Dr Mahbubul Haq and his team's work on Human Development Index, to another important step by including the negative impact of climate change. This paper uses carbondioxide emission of a given country as a proxy to capture the adverse effects on climate change and incorporates that into the HDI in a way that higher carbondioxide emissions lowers the HDI and renamed it as Clean Air Adjusted HDI. The new index changes the current HDI ranking of countries by pushing down the countries with heavy air pollution. Findings of this study can be useful specifically to countries with higher level of emissions to reconsider their relative ranking in terms of Clean Air Adjusted HDI, to bring down the emission levels. Further, International Agencies work on Human
\end{abstract}

\footnotetext{
"Sumanasiri Liyanage, M.Phil. Professor (Rtd) in Political Economy, University of Peradeniya, Sri Lanka.

** Anuruddha Kankanamge, Ph.D. Senior Lecturer in Economics, University of Peradeniya
} 
Development can give country specific recommendations to improve HDI ranking and also to mitigate adverse consequences on the environment.

Keywords: HDI, anthropocene, capitalocene, climate change, UNDP, vulnerability

The philosopher Jacques Derrida once wrote an essay called "Of an Apocalyptic Tone Recently Adopted in Philosophy". That tone has recently entered into everyday political discourse with the warnings of climatologists all over the world of the incoming avalanche of ecological disaster notwithstanding Donald Trump's victory in the recently held US Presidential Election. With the ambiguous term "sustainable" introduced into development lexicon in recent years, attempts have been made to resolve the issue without disturbing the status quo in the prevailing economic and social system. What is the nexus between climate change and economic and social development? How can this nexus be reflected in economic and social development indices? These and other associated questions remind us of seemingly unrelated two discourses in the recent years. The first is the debate on enlightenment. How rational is the enlightenment project? This is the question raised by Horkheimer and Adorno in their work, Dialectics of Enlightenment. The second issue refers to how development should be measured giving its human dimension a proper place. The team of development economists led by Dr. Mahbub ul Haq had focused on this aspect in the latter part of the last century.

Measuring the wealth of nations using extremely crude methods of calculation goes back at least to middle ages since the tax on production was the principal source of income of the ruling classes of the medieval society, both secular and ecclesiastical. How the tax system can be related to the level of production had invariably become one of the key problematic issues of the feudal ruling classes as well as the colonial masters. However, the method of calculation is not only crude but also spatially local. As Jairus Banaji (2010) (has revealed, the calculation in the middle ages depended on the surface in production and the size of the disposable labor-power. ${ }^{1}$ However, the process of modernity and the rise of the absolute state called for a more systematic collection of production data at national level. As David Landes has argued, Mercantilism had made it imperative the collection of economic and social statistics. ${ }^{2}$ An economist of Mercantilist tradition, William Petty has been regarded as the person who pioneered the modern system of national accounts.

The objectives of the collection of national income account varies significantly from time to time. Mercantilist ideas were advanced on the same cognitive basis of natural

\footnotetext{
1 "As the level of technique progressed only slowly, over several centuries, as our figures indicate, the estate's output was a function of the surface in production, and the surface which the lord could bring into production in any given period was a function of the disposable mass of labour-power.", Jairus Banaji, Theory as History: Essays on Mode of Production and Exploitation. (Boston: Brill, 2010) p.73

${ }^{2}$ David S Landes, The Unbound Prometheus: Technological Change and Industrial Development in Western Europe from 1750 to the Present. (UK: Cambridge University Press, n.d.) p.32.
} 
science so that the performance was the main criterion in the process of calculation. ${ }^{3}$ Whether an economy performs well or not at a given time thus depends on the size of its total output and the level of per capita income. So the time series data on national and per capita income and their growth are considered as the main indicators of economic performance. The implicit assumption is that the increase in per capita income would eventually increase the welfare of the people in the country. This assumption had been questioned with reference to income distribution between different classes of society. Hence, the supplementary data on income distribution is collected and the Gini coefficient is calculated to demonstrate how income levels are deviated from the average.

Dr. Mahbubul Haq's pioneering work were aimed at addressing a more qualitative dimension of economic and social progress bringing in the level of performance in the sphere of education and health. Following his footsteps and extending his vision, this paper submits a case that in the light of experience in the last three decades or so, the development index has to be added and enriched making them indicators of a more rational and humane economic growth. In contemporary world, the implications and effects of climate change can be considered as one of the key factors in determining not only the welfare of human being but also the existence of other life forms and our planet. Humanity's relationship with the rest of nature has always been a tricky issue. However, with the advent of modernity roughly about 300 years ago, the subject has become trickier.

The principal submission of this paper is that extending and advancing the insight of $\mathrm{Dr}$ Mahbubul Haq and his team, we should take another important step by including the negative impact of climate change into Human Development Index so that such an expanded composite index would contribute immensely in policy-making process. Thus the indices would be able to capture both the positive and negative dialectics of enlightenment and the modernization process.

The paper consists of five sections: First section discusses the multi-faceted nature of human progress and the inherent drawbacks of mono-focused measurement. Section 2 briefly presents how HDI has been calculated since 2010 while Section 3 focuses on the new challenge of development, the climate change. How we understand the climate change is the subject of Section 4. On the basis of that argument Section 5 briefly outlines how HDI be improved and expanded still as a composite index by incorporating the negative aspect of development. A brief conclusion will follow. The climate change adjusted HDI for all countries is given in the Appendix at the end.

\section{Multi-Faceted Progress and Mono-Focused Measurement}

The social progress and development has always been multi-dimensional. Nobel laureate Prof Amatya Sen has argued in the opening sentence of his book, Development as Freedom:

${ }^{3}$ Ibid. 
Development can be seen, .. as a process of expanding the real freedoms that people enjoy. Focusing on human freedoms contrasts with narrower views of development, such as identifying development with the growth of gross national product, or with the rise in real incomes, or with industrialization, or with technological advance, or with social modernization. ${ }^{4}$

Of course, it does not mean that the increase of GNP is of no importance. When Marx hypothesized the historical trajectory of human progress as from freedom to necessity and then from necessity to freedom, he emphasized the importance of increase in production as a material basis of freedom. It is interesting to note that there is a difference between the freedom at the point of departure and the freedom at the end point. Nonetheless, "freedoms depend also on other determinants, such as social and economic arrangements (for example, facilities of education and health care) as well as political and civil rights (for example, the liberty to participate in public discussion and scrutiny)" ${ }^{5}$ In the early development discourse, it had been surmised that the growth of GNP would sooner or later contribute to the improvements in social and economic arrangements and advance in political and civil rights. However, during the post-World War 2 long boom in the world economy, many countries experienced substantial growth in GNP and per capita income, but no significant gain in educational or health standards. On the contrary, in Sri Lanka, although its growth record was relatively poor, a significant progress had been made in the 1950s and 1960s in educational and health standards. This was one of the conundrums that the development economist had to encounter in defining and measuring economic development and social progress. In addition, the second problem had been how multi-dimensional social and economic progress could be captured by a single development index. In order to resolve these twin issues, Dr Mahbub ul Haq formed a group of well-known development economists including Paul Streeten, Frances Stewart, Gustav Ranis, Keith Griffin, Sudhir Anand, and Meghnad Desai. The team also worked with Prof Amartya Sen who developed capabilities approach in his studies on poverty.

Initially, there was a disagreement between Dr. Haq and Prof. Sen. Being an economist focusing more on theoretical and philosophical aspects, Prof. Sen was in a view that it was not easy to capture a very complex and multi-dimensional process in a single index. On the other hand, Dr Haq was not only an academician, but a person who was directly involved in policy making as a finance minister in Pakistan. Hence, he knew that the politicians and policy makers may not go with the philosophical arguments but would seek for tangible results in implementation of policies. Thus he emphasized the need of a single index that would attract immediate attention of the politicians. They finally reached a compromise that a composite index should be developed taking limited but highly important factors into consideration. ${ }^{6}$ In developing the Human Development

\footnotetext{
${ }^{4}$ Amartya Sen, Development as Freedom, (New Delhi: Oxford University Press, n.d.) p.3

${ }^{5}$ Ibid.

${ }^{6} \mathrm{https}: / /$ en.wikipedia.org/wiki/Human_Development_Index.
} 
Index, it had been suggested that three principal dimensions must be combined giving an equal weightage. They are:

1. A long and healthy life: Life expectancy at birth;

2. Education index: Mean years of schooling and Expected years of schooling; and

3. A decent standard of living: GNI per capita (PPP US\$).

Dr. Haq's contribution has had a deep rooted impact on development thinking and practice. His contribution has been appreciated and the notion of HDI has played an important role in designing UN millennium goals. Amartya Sen and Tam Dalyell termed Haq's work to have "brought about a major change in the understanding and statistical accounting of the process of development". ${ }^{7}$ Moreover, UN Millennium Development Goals were designed following the argument embedded in the HDI discourse.

\section{Human Development Index}

The calculating method of HDI has changed considerably in the last two decades. In its 2010 Human Development Report, the UNDP began using a new method of calculating the HDI. The geometric mean of the following three indices was used in calculating the HDI (The geometric mean is defined as the $n^{\text {th }}$ root of the Product of $n$ numbers).

\section{Life Expectancy Index (LEI) LE -20/ 85-20}

LEI is 1 when Life expectancy at birth is 85 and 0 when Life expectancy at birth is 20 .

\section{Education Index (EI) MYSI + EYSI/ 2}

2.1 Mean Years of Schooling Index (MYSI) MYS/ 15

Fifteen is the projected maximum of this indicator for 2025.

\subsection{Expected Years of Schooling Index (EYSI) EYS/ 18}

Eighteen is equivalent to achieving a master's degree in most countries.

3. Income Index (II) $\ln$ (GNIpc) - ln 100 / ln (75000) - ln (100)

II is 1 when GNI per capita is $\$ 75,000$ and 0 when GNI per capita is $\$ 100$.

Finally, the HDI is the geometric mean of the previous three normalized indices:

\footnotetext{
${ }^{7}$ The Economist. 2016-02-23 as quoted in www.wikipedia.com
} 


\title{
New Challenges to Human Development
}

The concept of human development should not be viewed as static but dynamic. When the development process encounters new challenges, the concept has to be reviewed, reread and developed in order to capture the new reality. The new reality embedded with so many challenges was comprehensively analyzed by Amartya Sen in his recent writings. He opines: "Development requires the removal of major sources of unfreedom: poverty as well as tyranny, poor economic opportunities as well as systematic social deprivation, neglect of public facilities as well as intolerance or over activity of repressive states. ${ }^{8} \mathrm{He}$ and many other writers have also raised the importance of gender equality as an indicator of human progress.

All these issues that have been raised in making the development multi-dimensional stems from the enlightenment project of the $18^{\text {th }}$ and $19^{\text {th }}$ centuries, i.e. to the process of modernity. One of the key issues that has been gradually coming to the fore is the emerging ecological disaster that is also a direct outcome of the modernist project. Its impact can be seen in every nook and corner of the globe today.

According to a monthly analysis of global temperatures by scientists at NASA's Goddard Institute for Space Studies (GISS) in New York, August 2016 was the warmest August in 136 years of modern record-keeping; air pollution in mega cities like Beijing and Delhi has reached an unbearable level. A report by the American Association for the Advancement of Science, the world's largest general scientific society puts the magnitude of the issue in the following words:

\begin{abstract}
Most projections of climate change presume that future changes - greenhouse gas emissions, temperature increases and effects such as sea level rise-will happen incrementally. A given amount of emission will lead to a given amount of temperature increase that will lead to a given amount of smooth incremental sea level rise. However, the geological record for the climate reflects instances where a relatively small change in one element of climate led to abrupt changes in the system as a whole. In other words, pushing global temperatures past certain thresholds could trigger abrupt, unpredictable and potentially irreversible changes that have massively disruptive and large-scale impacts. At that point, even if we do not add any additional $\mathrm{CO} 2$ to the atmosphere, potentially unstoppable processes are set in motion. We can think of this as sudden climate brake and steering failure where the problem and its consequences are no longer something we can control. ${ }^{9}$
\end{abstract}

It seems that the ecological impact of climate change has already passed the threshold point and the best symbolic example for this is what has already happened to the Australian Great Barrier Reef which is 25 million years old. Rowan Jacobsen has written its obituary.

For most of its life, the reef was the world's largest living structure, and the only one visible from space. It was 1,400 miles long, with 2,900 individual

\footnotetext{
${ }^{8}$ Amartya Sen, Op.cit. p.3

${ }^{9}$ Report by the American Association for the Advancement of Science, 2014
} 
reefs and 1,050 islands. In total area, it was larger than the United Kingdom, and it contained more biodiversity than all of Europe combined. It harbored 1,625 species of fish, 3,000 species of mollusk, 450 species of coral, 220 species of birds, and 30 species of whales and dolphins. Among its many other achievements, the reef was home to one of the world's largest populations of dugong and the largest breeding ground of green turtles. ${ }^{10}$

In spite of many international conferences and decisions, the problem remains essentially unresolved. This fact is even recognized by the World Bank in its recent report. The Report says:

As global warming approaches and exceeds 2-degrees Celsius, there is a risk of triggering nonlinear tipping elements. Examples include the disintegration of the West Antarctic ice sheet leading to more rapid sea-level rise, or largescale Amazon dieback drastically affecting ecosystems, rivers, agriculture, energy production, and livelihoods. This would further add to 21 st-century global warming and impact entire continents. ${ }^{11}$

Annual anthropogenic $\mathrm{CO} 2$ emission and their partitioning among atmosphere, land and ocean from 1750 to 2014 is shown in Figure 1.

Figure 1: CO2 Emission between 1750- 2014

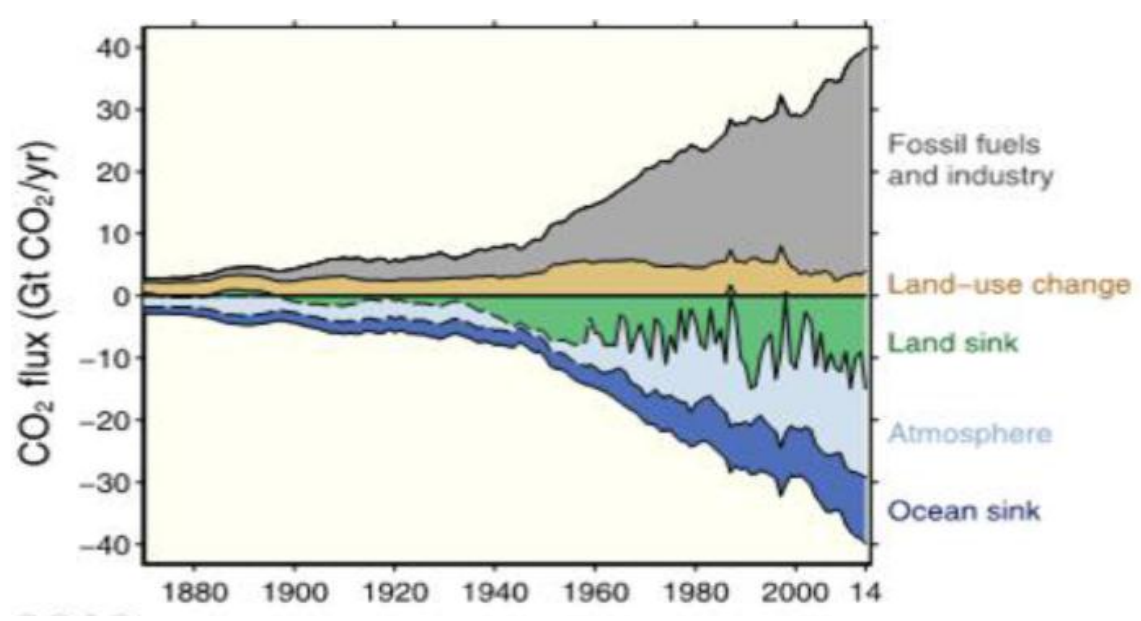

Source: Global Carbon Project. CDIAC/NOAA-ESRL/GCP/Joos et al. 2013/Khatiwala et al. 2013

A well-known climatologist and an activist on climate change, James Hanson has once mentioned that the world is moving towards a climate cliff. In such a situation, according to Kevin Anderson and Alice Bose of Manchester University, UK, the

\footnotetext{
${ }^{10} \mathrm{http}: / /$ www.spokesman.com/blogs/outdoors/2016/oct/13/great-barrier-reef-pronounced-dead-scientists/

${ }^{11}$ World Bank, Development Report 2012.

${ }^{12}$ As cited in: http://www.ipcc.ch/pdf/unfccc/specialevent_summaryreport_online.pdf
} 
intergovernmental agreement to maintain world warming within centigrade 2 limit may even become obsolete. They also argue that this would lead to submerging some areas under sea water, floods and the reduction in agricultural production. The concept of Planetary boundaries was developed as a central concept in an Earth system framework by a group led by Johan Rockström from the Stockholm Resilience Centre and Will Steffen from the Australian National University. They have identified nine boundaries marking "safe operating space for humanity". They assert that once human activity has passed certain thresholds or tipping points, defined as "planetary boundaries", there is a risk of "irreversible and abrupt environmental change". 13 The nine boundaries are: (1) climate change; (2) novel entities; (3) Stratospheric ozone deprivation; (4) atmospheric aerosol loading; (5) ocean acidification; (6) biogeochemical flows; (7) Freshwater use; (8) Land-system change; and (9) biosphere integrity.

Figure 2: Planetary Boundaries

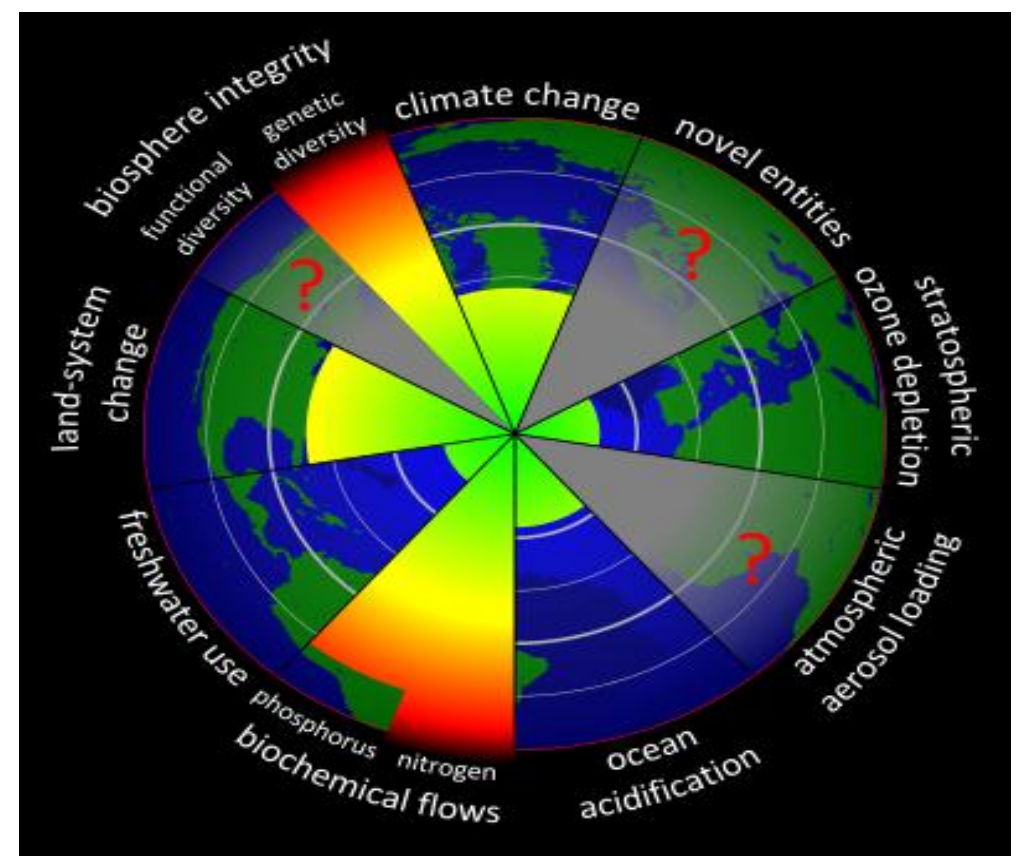

The green areas represent human activities that are within safe margins, the yellow areas represent human activities that may or may not have exceeded safe margins, the red areas represent human activities that have exceeded safe margins, and the gray areas

\footnotetext{
${ }^{13} \mathrm{https} / / /$ en.wikipedia.org/wiki/Planetary_boundaries
} 
with red question marks represent human activities for which safe margins have not yet been determined. ${ }^{14}$

Scientists during the last few years have sought to designate 'a safe operating space for humanity', constituted by nine planetary boundaries, nearly all of which now have either been crossed or are in the process of being crossed, as seen in: climate change; ocean acidification; destruction of the ozone layer; biosphere integrity; disruption of biochemical flows; land-system change, fresh water use, aerosol loading; and the introduction of novel entities (new chemical and biological substances). ${ }^{15}$

\section{Anthropocene or Capitalocene}

How do we explain this global phenomenon? As John Bellamy Foster and Paul Burkett argue "Standard, possessive-individualist social science, and much of contemporary environmental theory - in so far as it is an offshoot of the mainstream liberal tradition have found themselves incapable of going to the root of the problem in this respect". ${ }^{16}$ There are many attempts to understand the phenomenon of crossing planetary boundaries. One such attempt is to define the present epoch as Anthropoene. John Bellamy Foster has given the following definition for Anthropocene.

The Anthropocene, viewed as a new geological epoch displacing the Holocene epoch of the last 10,000 to 12,000 years, represents what has been called an "anthropogenic rift" in the history of the planet. Formally introduced into the contemporary scientific and environmental discussion by climatologist Paul Crutzen in 2000, it stands for the notion that human beings have become the primary emergent geological force affecting the future of the Earth system. Although often traced to the Industrial Revolution in the late eighteenth century, the Anthropocene is probably best seen as arising in the late 1940s and early 1950s. Recent scientific evidence suggests that the period from around 1950 on exhibits a major spike, marking a Great Acceleration in human impacts on the environment, with the most dramatic stratigraphic trace of the anthropogenic rift to be found in fallout radionuclides from nuclear weapons testing. ${ }^{17}$

It is true that since the industrial revolution and the process of modernity began, human impacts on nature and environment grew dramatically in leaps and bounds as the initial balance between humans and nature was redefined and transformed on the basis of the instrumental rationalist notion of the enlightenment project. While accepting that the initial balance between humans and nature had been disturbed owing to the fact that

\footnotetext{
${ }^{14}$ Steffen, W.; Richardson, K.; Rockstrom, J.; Cornell, S. E.; Fetzer, I.; Bennett, E. M.; Biggs, R.; Carpenter, S. R.; De Vries, W.; De Wit, C. A.; Folke, C.; Gerten, D.; Heinke, J.; Mace, G. M.; Persson, L. M.; Ramanathan, V.; Reyers, B.; Sorlin, S. (2015). "Planetary boundaries: Guiding human development on a changing planet”. Science. 347 (6223): 1259855; and https://en.wikipedia.org/wiki/Planetary_boundaries.

${ }^{15}$ John Bellamy Foster and Paul Burkett. Marx and the Earth: An Anti Critique. (New York: Monthly Review Press, 2017) p.222

${ }^{16}$ Ibid. p.223

${ }^{17}$ John Bellamy Foster. “Anthropocene Crisis”. Monthly Review. No. 68, Issue 4
} 
humans began to share the notion that it was the task of the humans to control and dominate everything in the interests of human well-being, some social scientists have questioned if humans in general could be blamed for this process. John W Moore has focused on this drawback of the Anthropocene idea.

The motive force behind this epochal shift? In two words: coal and steam. The driving force behind coal and steam? Not class. Not capital. Not imperialism. Not even culture. But... you guessed it, the Anthropos: humanity as an undifferentiated whole. ${ }^{18}$

He further added:

The Anthropocene makes for an easy story. Easy, because it does not challenge the naturalized inequalities, alienation, and violence inscribed in modernity's strategic relations of power and production. It is an easy story to tell because it does not ask us to think about these relations at all. The mosaic of human activity in the web of life is reduced to an abstract humanity as homogenous acting unit. Inequality, commodification, imperialism, patriarchy, and much more. 19

His principal criticism against the idea of Anthropocene is that the idea is mono-centric and has failed to capture the mosaic of developments that had been associated with the emergence and development of capitalist mode of production. Under capitalist mode of production the human-nature relationship has undergone a metamorphosis to promote the process of capital accumulation. The driving behind coal and steam and later fossil fuel and nuclear power are not humans in abstract but capital. Hence he coined with the term 'Capitalocene' in place of Anthropocene.

A somewhat essentially similar argument has been proposed by John Bellamy Foster, Paul Burkett and the Monthly Review group. Their point of departure is the statement by Marx and Engels. Karl Marx and Frederick Engels remarked as early as 1845, "Nature, the nature that preceded human history, no longer exists anywhere (except perhaps on a few Australian coral islands of recent origin)". ${ }^{20}$ This school argues that Marx and Engels have developed an outline (though in undeveloped or unfinished form) that can be used in developing a new theoretical framework that could capture the complexity of current ecological problem. It has been argued that the analysis should be based on the dialectical approach implicit in Marx's triadic scheme of "the universal metabolism of nature," the "social metabolism," and the metabolic rift. Hence John Bellamy Foster and Brett Clark opine:

In the Anthropocene epoch, it is therefore all the more necessary to explore the complex, dialectical natural-social interconnections between the Earth system as a whole and capitalism as a system of alienated social metabolic reproduction within that Earth system. Today the drive to capital accumulation is disrupting the planetary metabolism at cumulatively higher levels,

\footnotetext{
${ }^{18}$ John W Moore, "The Capitalocene: On the Nature and origins of Our Ecological Crisis". http://www.jasonwmoore.com/uploads/The_Capitalocene_Part_I_June_2014.pdf

${ }^{20}$ Karl Marx and Fredrick Engels. Collected Works. Vol. 5. (Moscow: Progress Publishers) p. 40
} 
threatening irreversible, catastrophic impacts for countless species, including our own. It is in the theorization of this ecological and social dialectic, and in the development of a meaningful praxis to address it, that Marx's analysis has proven indispensable. $^{21}$

When Marx's above cited triadic scheme is deployed in the analysis of the "climate cliff", climate change and ecological issues may be seen as a natural corollary of capitalist system of production in which in the "pursuit of profit, "capitalists are driven to accumulate ever more capital, and this becomes both their subjective goal and the motor force of the entire economic system". ${ }^{22}$ Hence climate change is not a "natural" disaster, but a creation of the system that is aimed in pursuit of private profit at increasing scale.

\section{Revisiting the HDI}

The above discussion leads us to focus on the negative aspects of the enlightenment project that had developed as a capitalist project. The dialectics of enlightenment while accepting the positive dimensions of modern development that are at the moment included in the calculation of HDI, forces us to embed negative dimensions as well as modern development. Hence we submit that climate change has to be introduced into the HDI calculation as a negative element. In this essay we do not make an attempt to calculate comprehensive composite index that embodies both the positive and negative aspects of modern development, but it makes an attempt to flag the idea by adding the negative factor using carbon emission as a proxy to HDI calculation.

Two suggestions may be made on how the incidence of climate change be incorporated into HDI index. First is linking the impact of climate change to health indices of the current HDI calculation. Although it may be easy to do so as far as the easiness of measurement is concerned, it is reductionist in the sense that climate changes affect only human health standards. The impact of climate change affects all other life forms and the existence of the planet. Hence it is not advisable to do so as it is still a trap us within modernist project.

The better way to incorporate climate change factor is to include it as a negative component to existing HDI. Hence, suppose Country A has high HDI value but it release higher level of carbon to the atmosphere. As a result, under this system, its HDI value will go down. On the other hand, suppose that Country B has lower HDI value but it emits no carbon to the atmosphere or lower than the accepted level of carbon. In final HDI calculation, the value of the HDI of Country B will go up (Table 1).

\footnotetext{
${ }^{21}$ John Bellamy Foster, Brett Clark. "Marx’s Ecology and the Left". Monthly Review. Vol. 68. Issue 2. (n.pub. 2016)

${ }^{22}$ Paul M Sweezy. Capitalism and the Environment, "Monthly Review56, No. 5 (2004): 86-93.
} 
Table 1: HDI Ranking of 10 Selected Countries

\begin{tabular}{|l|c|c|}
\hline $\begin{array}{c}\text { Country and Current } \\
\text { Group in HDI } \\
\text { Ranking }\end{array}$ & $\begin{array}{c}\text { HDI Rank-2014 (UNDP 2015 } \\
\text { Report. Ranking out of 188 } \\
\text { countries) }\end{array}$ & $\begin{array}{c}\text { Clean air adjusted HDI Rank } \\
\text { 2014 (out of 180 countries used } \\
\text { in the study) }\end{array}$ \\
\hline Very High HDI & 2 & 17 \\
\hline Australia & 6 & 113 \\
\hline Germany & 8 & 180 \\
\hline USA & 75 & 68 \\
\hline High HDI & 90 & 141 \\
\hline Brazil & 73 & 134 \\
\hline China & 152 & \\
\hline Sri Lanka & 110 & \\
\hline & & \\
\hline Medium HDI & 130 & \\
\hline Indonesia & & \\
\hline India & & \\
\hline & & \\
\hline Low HDI & & \\
\hline Pakistan & & 107 \\
\hline Nigeria & & \\
\hline See Appendia & & \\
\hline
\end{tabular}

See Appendix 1 for Calculation Method of Clean Air Adjusted HDI.

\section{Conclusion}

The principal submission of this paper is that extending and advancing the insight of Dr Mahbub ul Haq and his team, we should take another important step by including the negative impact of climate change into Human Development Index so that such an expanded composite index would contribute immensely in policy-making process. Particularly those countries that contribute a high level of carbon dioxide emissions have to make an extra effort to lower it. This paper shows, to what extent it affects the relative Ranking of HDI (Clean Air Adjusted HDI) by pulling down the HDI ranking of 
countries with high level of emissions. Such countries can reconsider their emission related domestic policies in terms of improving HDI. At the global level adverse effects of climate change will have amplified effect on vulnerable countries (As identified in the UNDP report on "Climate Change 2001: Impact Adaptation and Vulnerability). International agencies such as UNDP can emphasis this fact and can incorporate into country specific policy recommendations. 
Appendix: Table 1: Current and Clean Air Adjusted HDI for 2014 (for 180 Countries)

\begin{tabular}{|c|c|c|c|c|c|c|c|c|c|c|}
\hline No & Country & $\begin{array}{c}\text { Life } \\
\text { Expectancy } \\
\text { Index }^{\mathbf{a}}\end{array}$ & $\begin{array}{c}\text { Education } \\
\text { Index }^{\text {a }}\end{array}$ & $\begin{array}{c}\text { GNI } \\
\text { Index }^{\mathbf{a}}\end{array}$ & $\begin{array}{c}\mathrm{CO}_{2}^{\mathbf{b}} \\
\text { (Million } \\
\text { Metric } \\
\text { Tons) } \\
\end{array}$ & $\begin{array}{c}\text { Clean } \\
\text { Air } \\
\text { Index }\end{array}$ & HDI $^{\mathbf{a}}$ & $\begin{array}{c}\text { HDI } \\
\text { Rank }^{d}\end{array}$ & $\begin{array}{c}\text { Clean } \\
\text { Air } \\
\text { Adjusted } \\
\text { HDI }^{\mathbf{c}}\end{array}$ & $\begin{array}{c}\text { Clean } \\
\text { Air } \\
\text { Adjusted } \\
\text { HDI } \\
\text { Rank }^{\mathrm{e}}\end{array}$ \\
\hline 1 & Norway & 0.969011 & 0.933947 & 0.978366 & 40.005060 & 0.995431 & 0.944 & 1 & 0.968927 & 2 \\
\hline 2 & Australia & 0.981595 & 1.034130 & 0.913350 & 370.352477 & 0.957649 & 0.935 & 2 & 0.970706 & 1 \\
\hline 3 & Switzerland & 0.991034 & 0.882556 & 0.957029 & 39.623937 & 0.995475 & 0.930 & 3 & 0.955425 & 5 \\
\hline 4 & Denmark & 0.946988 & 0.976572 & 0.919530 & 35.544410 & 0.995941 & 0.923 & 4 & 0.959317 & 3 \\
\hline 5 & Netherlands & 0.969011 & 0.927703 & 0.924290 & 231.993993 & 0.973473 & 0.922 & 5 & 0.948347 & 7 \\
\hline 6 & Ireland & 0.957999 & 0.957851 & 0.903405 & 33.669397 & 0.996156 & 0.916 & 6 & 0.953275 & 6 \\
\hline 7 & Germany & 0.957999 & 0.911531 & 0.919162 & 742.413727 & 0.915097 & 0.916 & 6 & 0.925761 & 17 \\
\hline 8 & United States & 0.929684 & 0.908848 & 0.947402 & 5411.885620 & 0.381048 & 0.915 & 8 & 0.743165 & 113 \\
\hline 9 & New Zealand & 0.972157 & 0.985850 & 0.874558 & 37.634610 & 0.995702 & 0.913 & 9 & 0.955798 & 4 \\
\hline 10 & Canada & 0.975303 & 0.890393 & 0.912972 & 604.378417 & 0.930884 & 0.913 & 9 & 0.926869 & 13 \\
\hline 11 & Singapore & 0.991034 & 0.808611 & 1.003244 & 223.103087 & 0.974490 & 0.912 & 11 & 0.940812 & 10 \\
\hline 12 & $\begin{array}{l}\text { Hong Kong, } \\
\text { China }\end{array}$ & 1.006764 & 0.829919 & 0.950264 & 83.852597 & 0.990416 & 0.910 & 12 & 0.941687 & 9 \\
\hline 13 & Sweden & 0.978449 & 0.863148 & 0.924955 & 46.361797 & 0.994704 & 0.907 & 14 & 0.938879 & 11 \\
\hline 14 & $\begin{array}{l}\text { United } \\
\text { Kingdom }\end{array}$ & 0.954853 & 0.902059 & 0.902252 & 441.943503 & 0.949461 & 0.907 & 14 & 0.926817 & 14 \\
\hline 15 & Iceland & 0.984741 & 0.926730 & 0.885658 & 2.693120 & 0.999699 & 0.899 & 16 & 0.948097 & 8 \\
\hline 16 & $\begin{array}{l}\text { Korea } \\
\text { (Republic of) }\end{array}$ & 0.973730 & 0.892758 & 0.880008 & 631.166820 & 0.927820 & 0.898 & 17 & 0.917869 & 22 \\
\hline 17 & Israel & 0.981595 & 0.880218 & 0.864953 & 65.806511 & 0.992480 & 0.894 & 18 & 0.928024 & 12 \\
\hline 18 & Luxembourg & 0.970584 & 0.788055 & 0.963013 & 10.447417 & 0.998812 & 0.892 & 19 & 0.926139 & 15 \\
\hline 19 & Japan & 0.998899 & 0.830878 & 0.892970 & 1157.797420 & 0.867589 & 0.891 & 20 & 0.895473 & 30 \\
\hline
\end{tabular}




\begin{tabular}{|c|c|c|c|c|c|c|c|c|c|c|}
\hline 20 & Belgium & 0.956426 & 0.857532 & 0.909462 & 128.386950 & 0.985323 & 0.890 & 21 & 0.925905 & 16 \\
\hline 21 & France & 0.978449 & 0.842643 & 0.897521 & 327.617620 & 0.962537 & 0.888 & 22 & 0.918673 & 21 \\
\hline 22 & Austria & 0.965864 & 0.825841 & 0.918993 & 60.325693 & 0.993107 & 0.885 & 23 & 0.923698 & 19 \\
\hline 23 & Finland & 0.956426 & 0.854703 & 0.900034 & 42.074290 & 0.995195 & 0.883 & 24 & 0.925035 & 18 \\
\hline 24 & Slovenia & 0.950134 & 0.890540 & 0.850368 & 11.912337 & 0.998644 & 0.880 & 25 & 0.920691 & 20 \\
\hline 25 & Spain & 0.984741 & 0.844335 & 0.871550 & 264.015380 & 0.969811 & 0.876 & 26 & 0.915596 & 23 \\
\hline 26 & Italy & 0.992607 & 0.815340 & 0.876124 & 340.471273 & 0.961067 & 0.873 & 27 & 0.908571 & 27 \\
\hline 27 & $\begin{array}{l}\text { Czech } \\
\text { Republic }\end{array}$ & 0.921818 & 0.888556 & 0.843761 & 95.512630 & 0.989083 & 0.870 & 28 & 0.909276 & 26 \\
\hline 28 & Greece & 0.957999 & 0.872600 & 0.831145 & 70.764887 & 0.991913 & 0.865 & 29 & 0.911135 & 25 \\
\hline
\end{tabular}




\begin{tabular}{|c|c|c|c|c|c|c|c|c|c|c|}
\hline No & Country & $\begin{array}{c}\text { Life } \\
\text { Expectancy } \\
\text { Index }^{a}\end{array}$ & $\begin{array}{c}\text { Education } \\
\text { Index }^{\text {a }}\end{array}$ & $\begin{array}{c}\text { GNI } \\
\text { Index }\end{array}$ & $\begin{array}{c}\mathrm{CO}_{2}^{\mathbf{b}} \\
\text { (Million } \\
\text { Metric } \\
\text { Tons) }\end{array}$ & $\begin{array}{c}\text { Clean } \\
\text { Air } \\
\text { Index }\end{array}$ & HDI $^{\mathrm{a}}$ & $\begin{array}{c}\text { HDI } \\
\text { Rank }^{d}\end{array}$ & $\begin{array}{c}\text { Clean } \\
\text { Air } \\
\text { Adjusted } \\
\text { HDI }^{\mathbf{c}}\end{array}$ & $\begin{array}{c}\text { Clean } \\
\text { Air } \\
\text { Adjusted } \\
\text { HDI } \\
\text { Rank }^{\text {e }}\end{array}$ \\
\hline 29 & Estonia & 0.893503 & 0.896151 & 0.835336 & 5.179757 & 0.999414 & 0.861 & 30 & 0.904214 & 29 \\
\hline 30 & $\begin{array}{l}\text { Brunei } \\
\text { Darussalam }\end{array}$ & 0.924965 & 0.727875 & 0.995025 & 9.087277 & 0.998967 & 0.856 & 31 & 0.904465 & 28 \\
\hline 31 & Qatar & 0.915526 & 0.711519 & 1.074879 & 113.841957 & 0.986987 & 0.850 & 32 & 0.911763 & 24 \\
\hline 32 & Cyprus & 0.946988 & 0.788303 & 0.854543 & 7.009300 & 0.999205 & 0.850 & 32 & 0.893525 & 31 \\
\hline 33 & Slovakia & 0.885638 & 0.841743 & 0.839071 & 30.134580 & 0.996560 & 0.844 & 35 & 0.888556 & 32 \\
\hline 34 & Poland & 0.902942 & 0.843973 & 0.822610 & 280.589786 & 0.967916 & 0.843 & 36 & 0.882582 & 38 \\
\hline 35 & Malta & 0.953280 & 0.767156 & 0.850791 & 6.700000 & 0.999240 & 0.839 & 37 & 0.887972 & 33 \\
\hline 36 & Lithuania & 0.838446 & 0.890268 & 0.830999 & 13.382747 & 0.998476 & 0.839 & 37 & 0.887122 & 34 \\
\hline 37 & Saudi Arabia & 0.854176 & 0.784007 & 0.947044 & 575.837688 & 0.934148 & 0.837 & 39 & 0.877331 & 42 \\
\hline 38 & Argentina & 0.885638 & 0.871411 & 0.815078 & 188.856513 & 0.978407 & 0.836 & 40 & 0.885726 & 36 \\
\hline 39 & $\begin{array}{l}\text { United Arab } \\
\text { Emirates }\end{array}$ & 0.896649 & 0.707991 & 0.968463 & 229.374813 & 0.973773 & 0.835 & 41 & 0.879626 & 39 \\
\hline 40 & Chile & 0.970584 & 0.780065 & 0.809784 & 75.607806 & 0.991359 & 0.832 & 42 & 0.882960 & 37 \\
\hline 41 & Portugal & 0.957999 & 0.772862 & 0.838553 & 48.418897 & 0.994469 & 0.830 & 43 & 0.886436 & 35 \\
\hline 42 & Hungary & 0.868334 & 0.836163 & 0.820899 & 45.971926 & 0.994749 & 0.828 & 44 & 0.877496 & 41 \\
\hline 43 & Bahrain & 0.890357 & 0.741639 & 0.899658 & 39.560417 & 0.995482 & 0.824 & 45 & 0.876934 & 43 \\
\hline 44 & Latvia & 0.852603 & 0.826949 & 0.816652 & 6.950367 & 0.999212 & 0.819 & 46 & 0.870924 & 44 \\
\hline 45 & Croatia & 0.901369 & 0.799893 & 0.795814 & 17.520507 & 0.998003 & 0.818 & 47 & 0.869900 & 45 \\
\hline 46 & Kuwait & 0.855750 & 0.691745 & 1.017048 & 98.673707 & 0.988721 & 0.816 & 48 & 0.878369 & 40 \\
\hline 47 & Montenegro & 0.884065 & 0.815923 & 0.752369 & 2.207120 & 0.999754 & 0.802 & 49 & 0.858251 & 46 \\
\hline 48 & Belarus & 0.806984 & 0.854697 & 0.772886 & 64.402570 & 0.992641 & 0.798 & 50 & 0.852896 & 49 \\
\hline 49 & $\begin{array}{l}\text { Russian } \\
\text { Federation }\end{array}$ & 0.788108 & 0.821646 & 0.817136 & 1737.275590 & 0.801314 & 0.798 & 50 & 0.806941 & 78 \\
\hline
\end{tabular}




\begin{tabular}{|c|l|c|c|c|c|c|c|c|c|c|}
\hline 50 & Uruguay & 0.899796 & 0.751487 & 0.794830 & 8.612809 & 0.999022 & 0.793 & 52 & 0.856010 & 47 \\
\hline 51 & Oman & 0.893503 & 0.676745 & 0.884259 & 70.031223 & 0.991997 & 0.793 & 52 & 0.853400 & 48 \\
\hline 52 & Romania & 0.860469 & 0.773058 & 0.785329 & 68.747593 & 0.992144 & 0.793 & 52 & 0.848484 & 50 \\
\hline 53 & Bahamas & 0.871480 & 0.722979 & 0.810112 & 3.700000 & 0.999584 & 0.790 & 55 & 0.845156 & 52 \\
\hline 54 & Kazakhstan & 0.777096 & 0.818005 & 0.806754 & 209.224040 & 0.976078 & 0.788 & 56 & 0.841132 & 55 \\
\hline 55 & Barbados & 0.874626 & 0.804472 & 0.729194 & 1.818205 & 0.999799 & 0.785 & 57 & 0.846296 & 51 \\
\hline & $\begin{array}{l}\text { Antigua and } \\
\text { Barbuda }\end{array}$ & 0.882492 & 0.721688 & 0.800871 & 0.700000 & 0.999927 & 0.783 & 58 & 0.845080 & 53 \\
\hline
\end{tabular}




\begin{tabular}{|c|c|c|c|c|c|c|c|c|c|c|}
\hline No & Country & $\begin{array}{c}\text { Life } \\
\text { Expectancy } \\
\text { Index }^{\mathbf{a}}\end{array}$ & $\begin{array}{l}\text { Education } \\
\text { Index }^{\text {a }}\end{array}$ & $\begin{array}{c}\text { GNI } \\
\text { Index }^{\mathbf{a}}\end{array}$ & $\begin{array}{c}\mathrm{CO}_{2}^{\mathbf{b}} \\
\text { (Million } \\
\text { Metric } \\
\text { Tons) }\end{array}$ & $\begin{array}{c}\text { Clean } \\
\text { Air } \\
\text { Index }\end{array}$ & HDI $^{\mathbf{a}}$ & $\begin{array}{c}\text { HDI } \\
\text { Rank }^{d}\end{array}$ & $\begin{array}{c}\text { Clean } \\
\text { Air } \\
\text { Adjusted } \\
\text { HDI }^{\mathbf{c}}\end{array}$ & $\begin{array}{c}\text { Clean } \\
\text { Air } \\
\text { Adjusted } \\
\text { HDI } \\
\text { Rank }^{\mathrm{e}}\end{array}$ \\
\hline 57 & Bulgaria & 0.852603 & 0.771980 & 0.762771 & 48.065637 & 0.994509 & 0.782 & 59 & 0.840600 & 56 \\
\hline 58 & Panama & 0.906088 & 0.702300 & 0.786029 & 22.788970 & 0.997400 & 0.780 & 60 & 0.840427 & 57 \\
\hline 59 & Malaysia & 0.860469 & 0.701168 & 0.819883 & 225.703407 & 0.974193 & 0.779 & 62 & 0.833179 & 60 \\
\hline 60 & Mauritius & 0.855750 & 0.756509 & 0.779909 & 5.422100 & 0.999387 & 0.777 & 63 & 0.842820 & 54 \\
\hline 61 & Seychelles & 0.835300 & 0.707235 & 0.823413 & 1.000000 & 0.999892 & 0.772 & 64 & 0.835111 & 59 \\
\hline 62 & $\begin{array}{l}\text { Trinidad and } \\
\text { Tobago }\end{array}$ & 0.792827 & 0.713821 & 0.840495 & 56.575136 & 0.993536 & 0.772 & 64 & 0.829128 & 63 \\
\hline 63 & Serbia & 0.863615 & 0.770134 & 0.725556 & 44.794157 & 0.994884 & 0.771 & 66 & 0.832401 & 61 \\
\hline 64 & Lebanon & 0.932830 & 0.678381 & 0.771367 & 22.000000 & 0.997491 & 0.769 & 67 & 0.835337 & 58 \\
\hline 65 & Cuba & 0.934403 & 0.780683 & 0.648120 & 30.749676 & 0.996490 & 0.769 & 67 & 0.828484 & 64 \\
\hline 66 & Costa Rica & 0.934403 & 0.694500 & 0.739997 & 7.102177 & 0.999194 & 0.766 & 69 & 0.832284 & 62 \\
\hline 67 & $\begin{array}{l}\text { Iran (Islamic } \\
\text { Republic of) }\end{array}$ & 0.871480 & 0.730085 & 0.761250 & 645.973637 & 0.926127 & 0.766 & 69 & 0.818384 & 70 \\
\hline 68 & $\begin{array}{l}\text { Venezuela } \\
\text { (Bolivarian } \\
\text { Republic of) }\end{array}$ & 0.852603 & 0.721037 & 0.768127 & 180.154303 & 0.979402 & 0.762 & 71 & 0.824660 & 65 \\
\hline 69 & Turkey & 0.869907 & 0.694818 & 0.790004 & 319.661286 & 0.963447 & 0.761 & 72 & 0.823570 & 66 \\
\hline 70 & Sri Lanka & 0.863615 & 0.757112 & 0.692255 & 17.415470 & 0.998015 & 0.757 & 73 & 0.819824 & 68 \\
\hline 71 & Mexico & 0.893503 & 0.670573 & 0.767162 & 433.901603 & 0.950381 & 0.756 & 74 & 0.812984 & 75 \\
\hline 72 & Brazil & 0.857323 & 0.719225 & 0.758637 & 543.909943 & 0.937800 & 0.755 & 75 & 0.813838 & 74 \\
\hline 73 & Georgia & 0.863615 & 0.796284 & 0.645258 & 7.542080 & 0.999144 & 0.754 & 76 & 0.815995 & 71 \\
\hline 74 & $\begin{array}{l}\text { Saint Kitts } \\
\text { and Nevis }\end{array}$ & 0.845839 & 0.662155 & 0.806301 & 0.300000 & 0.999972 & 0.752 & 77 & 0.819753 & 69 \\
\hline 75 & Azerbaijan & 0.799119 & 0.708006 & 0.770621 & 37.095689 & 0.995764 & 0.751 & 78 & 0.811730 & 76 \\
\hline
\end{tabular}




\begin{tabular}{|l|l|l|l|l|l|l|l|l|l|l|}
\hline 76 & Grenada & 0.840019 & 0.764348 & 0.709195 & 0.300000 & 0.999972 & 0.750 & 79 & 0.821454 & 67 \\
\hline 77 & Jordan & 0.849457 & 0.725522 & 0.714968 & 22.795850 & 0.997400 & 0.748 & 80 & 0.814211 & 73 \\
\hline & $\begin{array}{l}\text { The former } \\
\text { Yugoslav }\end{array}$ & & & & & & & & & \\
78 & $\begin{array}{l}\text { Republic of } \\
\text { Macedonia }\end{array}$ & 0.871480 & 0.702332 & 0.720384 & 7.636083 & 0.999133 & 0.747 & 81 & 0.814698 & 72 \\
\hline 79 & Ukraine & 0.802265 & 0.819712 & 0.665256 & 225.943850 & 0.974165 & 0.747 & 81 & 0.807979 & 77 \\
\hline 80 & Algeria & 0.862042 & 0.676928 & 0.735899 & 142.172508 & 0.983746 & 0.736 & 83 & 0.806200 & 79 \\
\hline
\end{tabular}




\begin{tabular}{|c|c|c|c|c|c|c|c|c|c|c|}
\hline No & Country & $\begin{array}{c}\text { Life } \\
\text { Expectancy } \\
\text { Index }^{\mathbf{a}}\end{array}$ & $\begin{array}{c}\text { Education } \\
\text { Index }^{\mathrm{a}}\end{array}$ & $\begin{array}{c}\text { GNI } \\
\text { Index }\end{array}$ & $\begin{array}{c}\mathrm{CO}_{2}^{\mathbf{b}} \\
\text { (Million } \\
\text { Metric } \\
\text { Tons) }\end{array}$ & $\begin{array}{c}\text { Clean } \\
\text { Air } \\
\text { Index }\end{array}$ & HDI $^{\mathbf{a}}$ & $\begin{array}{c}\text { HDI } \\
\text { Rank }^{d}\end{array}$ & $\begin{array}{c}\text { Clean } \\
\text { Air } \\
\text { Adjusted } \\
\text { HDI }^{c}\end{array}$ & $\begin{array}{c}\text { Clean } \\
\text { Air } \\
\text { Adjusted } \\
\text { HDI } \\
\text { Rank }^{\mathbf{e}}\end{array}$ \\
\hline 81 & Peru & 0.858896 & 0.685891 & 0.710244 & 54.707007 & 0.993750 & 0.734 & 84 & 0.803008 & 82 \\
\hline 82 & $\begin{array}{l}\text { Bosnia and } \\
\text { Herzegovina }\end{array}$ & 0.888784 & 0.684617 & 0.690064 & 17.081690 & 0.998053 & 0.733 & 85 & 0.804585 & 81 \\
\hline 83 & Albania & 0.909234 & 0.651099 & 0.694772 & 4.342377 & 0.999510 & 0.733 & 85 & 0.800734 & 83 \\
\hline 84 & Armenia & 0.860469 & 0.712539 & 0.664245 & 6.182588 & 0.999300 & 0.733 & 85 & 0.798715 & 88 \\
\hline 85 & Ecuador & 0.879346 & 0.683095 & 0.704509 & 39.483871 & 0.995491 & 0.732 & 88 & 0.805640 & 80 \\
\hline 86 & Saint Lucia & 0.866761 & 0.678464 & 0.692043 & 0.400000 & 0.999961 & 0.729 & 89 & 0.798703 & 89 \\
\hline 87 & Fiji & 0.786535 & 0.798672 & 0.652030 & 2.300000 & 0.999744 & 0.727 & 90 & 0.799946 & 84 \\
\hline 88 & Mongolia & 0.777096 & 0.744245 & 0.706272 & 18.351520 & 0.997908 & 0.727 & 90 & 0.799030 & 87 \\
\hline 89 & China & 0.877773 & 0.645205 & 0.729912 & 8743.590059 & 0.000000 & 0.727 & 90 & 0.001091 & 180 \\
\hline 90 & Thailand & 0.855750 & 0.652467 & 0.738975 & 325.313167 & 0.962801 & 0.726 & 93 & 0.793904 & 92 \\
\hline 91 & Libya & 0.811704 & 0.670950 & 0.755985 & 57.558477 & 0.993424 & 0.724 & 94 & 0.799713 & 85 \\
\hline 92 & Dominica & 0.908652 & 0.640073 & 0.695544 & 0.100000 & 0.999995 & 0.724 & 94 & 0.797512 & 90 \\
\hline 93 & Tunisia & 0.862042 & 0.677385 & 0.701627 & 21.405487 & 0.997559 & 0.721 & 96 & 0.799562 & 86 \\
\hline 94 & Colombia & 0.849457 & 0.655684 & 0.723684 & 79.558637 & 0.990908 & 0.720 & 97 & 0.794977 & 91 \\
\hline 95 & $\begin{array}{l}\text { Saint Vincent } \\
\text { and the } \\
\text { Grenadines }\end{array}$ & 0.832154 & 0.686964 & 0.694687 & 0.200000 & 0.999984 & 0.720 & 97 & 0.793834 & 93 \\
\hline 96 & Jamaica & 0.876199 & 0.680465 & 0.650451 & 8.789880 & 0.999001 & 0.719 & 99 & 0.788946 & 97 \\
\hline 97 & Tonga & 0.830580 & 0.787500 & 0.593008 & 0.200000 & 0.999984 & 0.717 & 100 & 0.789171 & 96 \\
\hline 98 & $\begin{array}{l}\text { Dominican } \\
\text { Republic }\end{array}$ & 0.841592 & 0.646112 & 0.721694 & 20.860197 & 0.997621 & 0.715 & 101 & 0.791010 & 94 \\
\hline 99 & Belize & 0.786535 & 0.743034 & 0.654458 & 0.500000 & 0.999950 & 0.715 & 101 & 0.786406 & 99 \\
\hline 100 & Suriname & 0.803838 & 0.635569 & 0.762977 & 2.700000 & 0.999698 & 0.714 & 103 & 0.790092 & 95 \\
\hline
\end{tabular}




\begin{tabular}{|l|l|c|c|c|c|c|c|c|c|c|}
\hline 101 & Maldives & 0.893503 & 0.594084 & 0.727256 & 1.700000 & 0.999812 & 0.706 & 104 & 0.788202 & 98 \\
\hline 102 & Samoa & 0.840019 & 0.715727 & 0.600517 & 0.200000 & 0.999984 & 0.702 & 105 & 0.775155 & 100 \\
\hline 103 & Botswana & 0.700016 & 0.662823 & 0.772615 & 5.034310 & 0.999431 & 0.698 & 106 & 0.773669 & 101 \\
\hline & $\begin{array}{l}\text { Moldova } \\
\text { (Republic of) }\end{array}$ & 0.811704 & 0.706339 & 0.597526 & 7.990043 & 0.999093 & 0.693 & 107 & 0.764880 & 103 \\
\hline 105 & Egypt & 0.803838 & 0.632886 & 0.703186 & 210.878807 & 0.975888 & 0.690 & 108 & 0.768672 & 102 \\
\hline 106 & Turkmenistan & 0.717319 & 0.634512 & 0.736036 & 81.631963 & 0.990670 & 0.688 & 109 & 0.759006 & 106 \\
\hline 107 & Gabon & 0.698443 & 0.633165 & 0.770059 & 5.737173 & 0.999351 & 0.684 & 110 & 0.763787 & 104 \\
\hline 108 & Indonesia & 0.769231 & 0.643696 & 0.692407 & 537.696847 & 0.938510 & 0.684 & 110 & 0.753155 & 107 \\
\hline
\end{tabular}




\begin{tabular}{|c|c|c|c|c|c|c|c|c|c|c|}
\hline No & Country & $\begin{array}{c}\text { Life } \\
\text { Expectancy } \\
\text { Index }^{\mathbf{a}}\end{array}$ & $\begin{array}{l}\text { Education } \\
\text { Index }^{\mathrm{a}}\end{array}$ & $\begin{array}{c}\text { GNI } \\
\text { Index }\end{array}$ & $\begin{array}{c}\mathrm{CO}_{2}^{\mathbf{b}} \\
\text { (Million } \\
\text { Metric } \\
\text { Tons) }\end{array}$ & $\begin{array}{c}\text { Clean } \\
\text { Air } \\
\text { Index }\end{array}$ & HDI $^{\mathrm{a}}$ & $\underset{\text { Rank }^{\text {d }}}{\text { HDI }}$ & $\begin{array}{c}\text { Clean } \\
\text { Air } \\
\text { Adjusted } \\
\text { HDI }^{c}\end{array}$ & $\begin{array}{c}\text { Clean } \\
\text { Air } \\
\text { Adjusted } \\
\text { HDI } \\
\text { Rank }^{\mathrm{e}}\end{array}$ \\
\hline 109 & Paraguay & 0.832154 & 0.611024 & 0.655042 & 5.200000 & 0.999412 & 0.679 & 112 & 0.759572 & 105 \\
\hline 110 & Uzbekistan & 0.761365 & 0.685309 & 0.607160 & 103.829150 & 0.988132 & 0.675 & 114 & 0.747996 & 109 \\
\hline 111 & Philippines & 0.758219 & 0.622652 & 0.660320 & 92.415587 & 0.989437 & 0.668 & 115 & 0.745239 & 112 \\
\hline 112 & El Salvador & 0.833727 & 0.589484 & 0.649119 & 6.600000 & 0.999252 & 0.666 & 116 & 0.751404 & 108 \\
\hline 113 & Viet Nam & 0.877773 & 0.603611 & 0.593682 & 138.233877 & 0.984197 & 0.666 & 116 & 0.745922 & 110 \\
\hline 114 & South Africa & 0.588328 & 0.728132 & 0.724710 & 454.527957 & 0.948022 & 0.666 & 116 & 0.736551 & 114 \\
\hline 115 & Bolivia & 0.759792 & 0.664915 & 0.612310 & 19.280313 & 0.997802 & 0.662 & 119 & 0.745365 & 111 \\
\hline 116 & Kyrgyzstan & 0.795973 & 0.711182 & 0.515981 & 9.138697 & 0.998961 & 0.655 & 120 & 0.734963 & 116 \\
\hline 117 & Iraq & 0.777096 & 0.513305 & 0.746498 & 144.165323 & 0.983518 & 0.654 & 121 & 0.735640 & 115 \\
\hline 118 & Guyana & 0.729904 & 0.580076 & 0.631068 & 2.000000 & 0.999778 & 0.636 & 124 & 0.718923 & 119 \\
\hline 119 & Nicaragua & 0.863615 & 0.550300 & 0.573552 & 4.700000 & 0.999469 & 0.631 & 125 & 0.722463 & 118 \\
\hline 120 & Morocco & 0.849457 & 0.506783 & 0.638491 & 51.700067 & 0.994094 & 0.628 & 126 & 0.722997 & 117 \\
\hline 121 & Namibia & 0.704735 & 0.550895 & 0.686577 & 3.559233 & 0.999600 & 0.628 & 126 & 0.718460 & 121 \\
\hline 122 & Guatemala & 0.814850 & 0.511881 & 0.640224 & 13.296000 & 0.998486 & 0.627 & 128 & 0.718588 & 120 \\
\hline 123 & Tajikistan & 0.777096 & 0.662463 & 0.487277 & 3.162933 & 0.999645 & 0.624 & 129 & 0.707644 & 123 \\
\hline 124 & India & 0.755073 & 0.539609 & 0.605262 & 1772.402833 & 0.797297 & 0.609 & 130 & 0.665898 & 134 \\
\hline 125 & Honduras & 0.835300 & 0.522321 & 0.554855 & 8.280120 & 0.999060 & 0.606 & 131 & 0.701274 & 124 \\
\hline 126 & Bhutan & 0.778669 & 0.504285 & 0.645500 & 0.584220 & 0.999940 & 0.605 & 132 & 0.709537 & 122 \\
\hline 127 & Timor-Leste & 0.758219 & 0.511949 & 0.601507 & 0.800000 & 0.999915 & 0.595 & 133 & 0.695114 & 125 \\
\hline 128 & $\begin{array}{l}\text { Syrian Arab } \\
\text { Republic }\end{array}$ & 0.780242 & 0.582615 & 0.499426 & 35.046933 & 0.995998 & 0.594 & 134 & 0.689581 & 126 \\
\hline 129 & Vanuatu & 0.816423 & 0.542164 & 0.503492 & 0.100000 & 0.999995 & 0.594 & 134 & 0.687083 & 127 \\
\hline 130 & Congo & 0.665408 & 0.539546 & 0.618769 & 6.576370 & 0.999255 & 0.591 & 136 & 0.686405 & 128 \\
\hline
\end{tabular}




\begin{tabular}{|l|l|l|l|l|l|l|l|l|l|l|}
\hline 131 & $\begin{array}{l}\text { Equatorial } \\
\text { Guinea }\end{array}$ & 0.591474 & 0.451069 & 0.808113 & 4.764143 & 0.999462 & 0.587 & 138 & 0.681325 & 130 \\
\hline 132 & Zambia & 0.630801 & 0.633333 & 0.546833 & 3.365000 & 0.999622 & 0.586 & 139 & 0.683603 & 129 \\
\hline 133 & Ghana & 0.651251 & 0.577837 & 0.551531 & 13.465906 & 0.998467 & 0.579 & 140 & 0.674706 & 132 \\
\hline & $\begin{array}{l}\text { Lao People's } \\
\text { Democratic } \\
\text { Republic }\end{array}$ & 0.726758 & 0.491500 & 0.580945 & 0.962050 & 0.999897 & 0.575 & 141 & 0.674918 & 131 \\
\hline 135 & Bangladesh & 0.811704 & 0.473421 & 0.523117 & 64.294250 & 0.992653 & 0.570 & 142 & 0.668360 & 133 \\
\hline 136 & Cambodia & 0.761365 & 0.484858 & 0.511177 & 4.870360 & 0.999450 & 0.555 & 143 & 0.658999 & 135 \\
\hline
\end{tabular}




\begin{tabular}{|c|c|c|c|c|c|c|c|c|c|c|}
\hline No & Country & $\begin{array}{c}\text { Life } \\
\text { Expectancy } \\
\text { Index }^{\mathrm{a}} \\
\end{array}$ & $\begin{array}{l}\text { Education } \\
\text { Index }^{\mathrm{a}}\end{array}$ & $\begin{array}{c}\text { GNI } \\
\text { Index }^{\text {a }}\end{array}$ & $\begin{array}{c}\mathrm{CO}_{2}^{\mathbf{b}} \\
\text { (Million } \\
\text { Metric } \\
\text { Tons) } \\
\end{array}$ & $\begin{array}{c}\text { Clean } \\
\text { Air } \\
\text { Index }\end{array}$ & HDI $^{\mathbf{a}}$ & $\begin{array}{c}\text { HDI } \\
\text { Rank }^{d}\end{array}$ & $\begin{array}{c}\text { Clean Air } \\
\text { Adjusted } \\
\text { HDI }^{\mathbf{c}} \\
\end{array}$ & $\begin{array}{c}\text { Clean Air } \\
\text { Adjusted } \\
\text { HDI Rank } \\
\end{array}$ \\
\hline 137 & $\begin{array}{l}\text { Sao Tome and } \\
\text { Principe }\end{array}$ & 0.731477 & 0.505800 & 0.509596 & 0.100000 & 0.999995 & 0.555 & 143 & 0.658948 & 136 \\
\hline 138 & Nepal & 0.780242 & 0.503713 & 0.474372 & 4.528810 & 0.999489 & 0.548 & 145 & 0.657018 & 137 \\
\hline 139 & Kenya & 0.654397 & 0.540317 & 0.501263 & 14.736000 & 0.998321 & 0.548 & 145 & 0.648569 & 138 \\
\hline 140 & Pakistan & 0.726758 & 0.391107 & 0.586836 & 146.755183 & 0.983222 & 0.538 & 147 & 0.636376 & 141 \\
\hline 141 & Myanmar & 0.722039 & 0.401178 & 0.578590 & 18.248280 & 0.997920 & 0.536 & 148 & 0.639501 & 139 \\
\hline 142 & Angola & 0.508101 & 0.510955 & 0.637862 & 32.224163 & 0.996321 & 0.532 & 149 & 0.637330 & 140 \\
\hline 143 & Swaziland & 0.456190 & 0.575564 & 0.606487 & 1.068520 & 0.999884 & 0.531 & 150 & 0.631688 & 142 \\
\hline 144 & $\begin{array}{l}\text { Tanzania (United } \\
\text { Republic of) }\end{array}$ & 0.707881 & 0.447906 & 0.480784 & 10.145473 & 0.998846 & 0.521 & 151 & 0.624667 & 143 \\
\hline 145 & Nigeria & 0.515967 & 0.464804 & 0.600903 & 96.787437 & 0.988937 & 0.514 & 152 & 0.614421 & 145 \\
\hline 146 & Cameroon & 0.558440 & 0.512156 & 0.503533 & 8.360217 & 0.999051 & 0.512 & 153 & 0.615883 & 144 \\
\hline 147 & Madagascar & 0.709454 & 0.512829 & 0.390700 & 3.306280 & 0.999629 & 0.510 & 154 & 0.613966 & 147 \\
\hline 148 & Zimbabwe & 0.589901 & 0.563084 & 0.420267 & 8.561490 & 0.999028 & 0.509 & 155 & 0.611102 & 151 \\
\hline 149 & Mauritania & 0.677993 & 0.388065 & 0.539628 & 2.200000 & 0.999755 & 0.506 & 156 & 0.613803 & 148 \\
\hline 150 & $\begin{array}{l}\text { Solomon } \\
\text { Islands }\end{array}$ & 0.753500 & 0.448015 & 0.413039 & 0.200000 & 0.999984 & 0.506 & 156 & 0.611069 & 152 \\
\hline 151 & $\begin{array}{l}\text { Papua New } \\
\text { Guinea }\end{array}$ & 0.670127 & 0.439713 & 0.483967 & 6.812227 & 0.999228 & 0.505 & 158 & 0.614401 & 146 \\
\hline 152 & Comoros & 0.681139 & 0.511066 & 0.404546 & 0.200000 & 0.999984 & 0.503 & 159 & 0.612588 & 149 \\
\hline 153 & Yemen & 0.689004 & 0.377389 & 0.537894 & 22.762409 & 0.997403 & 0.498 & 160 & 0.611146 & 150 \\
\hline 154 & Lesotho & 0.468775 & 0.534552 & 0.528438 & 0.800000 & 0.999915 & 0.497 & 161 & 0.603223 & 153 \\
\hline 155 & Togo & 0.624508 & 0.531761 & 0.378863 & 1.900000 & 0.999789 & 0.484 & 162 & 0.595540 & 154 \\
\hline 156 & Rwanda & 0.695297 & 0.446293 & 0.404781 & 0.900000 & 0.999904 & 0.483 & 163 & 0.595309 & 155 \\
\hline 157 & Haiti & 0.673274 & 0.424489 & 0.425167 & 2.700000 & 0.999698 & 0.483 & 163 & 0.590366 & 157 \\
\hline 158 & Uganda & 0.605632 & 0.476185 & 0.419998 & 4.000000 & 0.999549 & 0.483 & 163 & 0.589874 & 158 \\
\hline
\end{tabular}




\begin{tabular}{|l|l|c|c|c|c|c|c|c|c|c|}
\hline 159 & Benin & 0.622935 & 0.460664 & 0.433808 & 5.900000 & 0.999332 & 0.480 & 166 & 0.593893 & 156 \\
\hline 160 & Sudan & 0.684285 & 0.320325 & 0.549831 & 16.000000 & 0.998177 & 0.479 & 167 & 0.588933 & 159 \\
\hline 161 & Djibouti & 0.660689 & 0.319884 & 0.527075 & 1.000000 & 0.999892 & 0.470 & 168 & 0.577702 & 162 \\
\hline 162 & South Sudan & 0.561586 & 0.401201 & 0.475729 & 16.000000 & 0.998177 & 0.467 & 169 & 0.571921 & 163 \\
\hline 163 & Senegal & 0.731477 & 0.333652 & 0.466101 & 7.065827 & 0.999199 & 0.466 & 170 & 0.580640 & 160 \\
\hline 164 & Afghanistan & 0.635520 & 0.398869 & 0.443603 & 22.081640 & 0.997481 & 0.465 & 171 & 0.578715 & 161 \\
\hline
\end{tabular}




\begin{tabular}{|c|c|c|c|c|c|c|c|c|c|c|}
\hline No & Country & $\begin{array}{c}\text { Life } \\
\text { Expectancy } \\
\text { Index }^{\mathrm{a}}\end{array}$ & $\begin{array}{l}\text { Education } \\
\text { Index }^{\mathrm{a}}\end{array}$ & $\begin{array}{c}\text { GNI } \\
\text { Index }\end{array}$ & $\begin{array}{c}\mathrm{CO}_{2}^{\mathbf{b}} \\
\text { (Million } \\
\text { Metric } \\
\text { Tons) }\end{array}$ & $\begin{array}{l}\text { Clean } \\
\text { Air } \\
\text { Index }\end{array}$ & HDI $^{\mathrm{a}}$ & $\begin{array}{c}\text { HDI } \\
\text { Rank }^{d}\end{array}$ & $\begin{array}{c}\text { Clean } \\
\text { Air } \\
\text { Adjusted } \\
\text { HDI }^{\mathrm{c}}\end{array}$ & $\begin{array}{c}\text { Clean Air } \\
\text { Adjusted } \\
\text { HDI } \\
\text { Rank }^{\mathrm{e}}\end{array}$ \\
\hline 165 & Malawi & 0.673274 & 0.477626 & 0.303824 & 1.184180 & 0.999871 & 0.445 & 173 & 0.559064 & 164 \\
\hline 166 & Ethiopia & 0.693723 & 0.350342 & 0.401601 & 9.844368 & 0.998881 & 0.442 & 174 & 0.558788 & 165 \\
\hline 167 & Gambia & 0.632374 & 0.370644 & 0.409803 & 0.500000 & 0.999950 & 0.441 & 175 & 0.556700 & 166 \\
\hline 168 & $\begin{array}{l}\text { Congo } \\
\text { (Democratic } \\
\text { Republic of } \\
\text { the) }\end{array}$ & 0.608778 & 0.491944 & 0.289667 & 3.804590 & 0.999572 & 0.433 & 176 & 0.542653 & 168 \\
\hline 169 & Liberia & 0.643385 & 0.430278 & 0.315043 & 1.000000 & 0.999892 & 0.430 & 177 & 0.543420 & 167 \\
\hline 170 & $\begin{array}{l}\text { Guinea- } \\
\text { Bissau }\end{array}$ & 0.553720 & 0.380327 & 0.394527 & 0.400000 & 0.999961 & 0.420 & 178 & 0.536880 & 170 \\
\hline 171 & Mali & 0.597766 & 0.337671 & 0.417201 & 1.100000 & 0.999881 & 0.419 & 179 & 0.538678 & 169 \\
\hline 172 & Mozambique & 0.552147 & 0.399513 & 0.365400 & 6.513967 & 0.999262 & 0.416 & 180 & 0.532732 & 171 \\
\hline 173 & Sierra Leone & 0.486078 & 0.370779 & 0.434950 & 1.100000 & 0.999881 & 0.413 & 181 & 0.529118 & 173 \\
\hline 174 & Guinea & 0.610351 & 0.357185 & 0.361632 & 2.500000 & 0.999721 & 0.411 & 182 & 0.529852 & 172 \\
\hline 175 & Burkina Faso & 0.608778 & 0.297176 & 0.417935 & 3.100000 & 0.999652 & 0.402 & 183 & 0.524333 & 174 \\
\hline 176 & Burundi & 0.577316 & 0.411446 & 0.306001 & 0.200000 & 0.999984 & 0.400 & 184 & 0.519231 & 175 \\
\hline 177 & Chad & 0.497090 & 0.300239 & 0.458834 & 0.300000 & 0.999972 & 0.392 & 185 & 0.511548 & 176 \\
\hline 178 & Eritrea & 0.687431 & 0.243876 & 0.366304 & 0.500000 & 0.999950 & 0.391 & 186 & 0.497800 & 177 \\
\hline 179 & $\begin{array}{l}\text { Central } \\
\text { African } \\
\text { Republic }\end{array}$ & 0.482932 & 0.358780 & 0.265725 & 0.400000 & 0.999961 & 0.350 & 187 & 0.463215 & 179 \\
\hline 180 & Niger & 0.651251 & 0.221033 & 0.333297 & 2.376150 & 0.999735 & 0.348 & 188 & 0.467983 & 178 \\
\hline
\end{tabular}

Notes: ${ }^{a}$ Source: UNDP Human Development Report 
${ }^{\mathrm{b}} \mathrm{CO}_{2}$; (Carbon dioxide emissions for a given country in millions of metric tons: Source: U.S. Energy Information Administration - http://www.eia.gov/beta/international/data/

${ }^{\mathrm{c}}$ Authors' computation.

${ }^{d}$ Ranking given here consider the countries in the UNDP (2014) report Accordingly some countries have given the same rank when the HDI takes the same value). Total number of countries in the UNDP report (2014) was 188. Our study has only 180 countries due to availability of $\mathrm{CO}_{2}$ emission data

${ }^{\mathrm{e}}$ Clean Air Adjusted HDI Ranking is out of the 180 countries used in this study. 


\section{Computation of Clean Air Adjusted Human Development Index.}

Computation of Clean Air Index was based on the information provided in the UNDP Human Development Reports (see calculating the Indices: www.hdr.undp.org/en/content/calculating-indices)

Current computation of HDI consists of three components; Life Expectancy Index, Education Index and GNI Index (Gross National Income). HDI is computed for a given country by taking the geometric mean of these three components. The new index developed in this study incorporates a fourth component and HDI was named as Clean Air Adjusted HDI. It is the geometric mean of the said four components. With the Clean Air Adjusted HDI it can be clearly seen how existing rankings change for the countries with greater pollution.

The Clean Air Index was computed using the country wise carbon dioxide $\left(\mathrm{CO}_{2}\right)$ emissions (million metric tones per year) given in US EIA web page for all countries. Clean Air Index was computed as given below. In order to give a lower HDI value for countries with greater pollution one minus $\mathrm{CO}_{2}$ emission factor (Component in the square bracket which is a value between zero and one). For the country with highest $\mathrm{CO}_{2}$ emission this factor is equal to one which makes the clean Air Index 0. For the country with lowest $\mathrm{CO}_{2}$ emission this factor is equal to zero which results in Clean Air Index equal to one. Accordingly Clean Air Index is a value between zero and one.

$$
\text { Clean Air Index } x_{i}=1-\left[\frac{\left(E_{\mathrm{CO}_{2}}\right)_{i}-(\text { Global Min CO2 })}{(\text { Global Max CO2 })-(\text { Global Min CO2 })}\right]
$$

where,

Clean Air Index $i=$ Clean Air Index for a country $i$ (for a given year)

$\left(E_{\mathrm{CO}_{2}}\right)=\mathrm{CO}_{2}$ emission for a country i for a given year

$\left(\right.$ Global Min $\left.\mathrm{CO}_{2}\right)=$ minimum $\mathrm{CO}_{2}$ emission for the year in consideration (country with lowest $\mathrm{CO}_{2}$ emissions)

(Global Max $\left.\mathrm{CO}_{2}\right)=$ maximum $\mathrm{CO}_{2}$ emission for the year in consideration (country with highest $\mathrm{CO}_{2}$ emissions)

\section{Data Sources}

(1) Data related to HDI obtained from UNDP Human Development Report (2014) (http://hdr.undp.org/en/content/human-development-index-hdi (see all 2015 data by indicator year and country)).

(2) $\mathrm{CO}_{2}$ emission data (2014): U.S. Energy Information Administration http://www.eia.gov/beta/international/data/ 